\title{
Efektivitas Penggunaan Model Pembelajaran Problem Based Learning Terhadap Kemampuan Membaca Pemahaman
}

\author{
Budi Febriyanto, Ari Yanto \\ Universitas Majalengka \\ budifebriyanto88@gmail.com
}

\section{Sejarah Artikel}

diterima 30/03/2019

\begin{abstract}
The research aims to examine the effectiveness of understanding reading ability of elementary school. It is between experimental classes implementing the PBL learning model and control classes applying direct instruction learning. This research uses quantitative approaches with experimental quasi methods. The research design uses Nonequivalent Control Groups Design (NCGD). The research subjects are primary schools in Depok District Cirebon Regency. The instruments are understanding reading worksheets. The data collection techniques are pre test and post test. It concludes that the PBL models are more effective in enhancing the reading comprehension skills than the control class using conventional learning.

Keyword: problem based learning model, understanding reading ability
\end{abstract}

\section{Abstrak}

Penelitian ini bertujuan untuk menguji efektivitas kemampuan membaca pemahaman siswa sekolah dasar antara kelas eksperimen yang menerapkan model pembelajaran PBL dengan kelas kontrol yang menerapkan pembelajaran direct instruction. Dalam penelitian ini digunakan pendekatan kuantitatif dengan metode kuasi eksperimen. Desain penelitian menggunakan Nonequivalent Control Groups Design (NCGD). Sekolah yang akan dijadikan lokasi penelitian adalah Sekolah Dasar yang berada di lingkungan UPT Kecamatan Depok Kabupaten Cirebon. Instrumen berupa lembar soal membaca pemahaman. Teknik pengumpulan data yaitu prates dan post tes. Berdasarkan hasil penelitian diperoleh kesimpulan bahwa model PBL lebih efektif dalam meningkatkan kemampuan membaca pemahaman dibandingkan kelas kontrol yang menggunakan pembelajaran konvensional.

Kata kunci: model problem based learning, kemampuan membaca pemahaman.

e-ISSN 2581-1835

p-ISSN 2581-1843 


\section{PENDAHULUAN}

Membaca pemahaman merupakan salah satu kemampuan yang memang harus di berkembang. Sejak tahun 2000 kemampuan membaca pemahaman merupakan salah satu kompetensi yang sudah dijadikan sebagai kemampuan yang dimiliki oleh siswa dati tingkat dasar (SD) hingga menengah pertama (SMP). Febriyanto (2016) mengemukakan bahwa pembelajaran membaca pemahaman di SD melalui mata pelajaran bahasa Indonesia yaitu pentingnya membaca untuk menggali informasi harus disertai dengan keterampilan membaca yang baik sehingga membaca menjadi efektif bagi siswaDari data survei Progress In International Reading Literacy Study (PIRLS) yang dilaksanakan pada tahun 2011 rerata siswa kelas IV sekolah dasar di Indonesia memperoleh skor 405 per 1000 , sehingga dapat dikategorikan memiliki kompetensi "rendah" (400474), (Abidin, 2013: 3).

Lebih lanjut Abidin (2013: 3) juga menyebutkan sebagai bahan perbandingan lebih dari 95\% siswa di Indonesia hanya mencapai level menengah, sementara lebih dari $50 \%$ siswa Taiwan mampu mencapai level tinggi dan advance. Dengan demikian merujuk kepada pernyataan bahwa manusia diciptakan dengan segala kesempurnaan dan memiliki kemampuan yang sama, demikian dapat disimpulkan bahwa proses pengajaran yang di terapkan di Indonesia tidak sama atau berbeda dengan yang telah di tetapkan atau di standarkan (dalam pengujiannya) oleh Internasional.
Berbagai temuan di kelas mengungkapkan bahwa pembelajaran Bahasa dan Sastra Indonesia di sekolah dasar belum berlangsung seperti yang diharapkan. Guru cenderung menggunakan teknik pembelajaran yang bercorak teoretis dan hafalan sehingga kegiatan pembelajaran berlangsung kaku, monoton, dan membosankan. Berbagai alasan yang di ungkapkan tadi bukan tanpa alasan karena pada penilaian kemampuan membaca pemahaman yang dilakukan oleh Programme for International Student Assessment (PISA) menunjukan bahwa Indonesia merupakan negara yang memiliki tingkat kemampuan membaca rendah. Berdasarkan penilaian PISA pada tahun 2000 bahwa Indonesia mempunyai skor 371 sehingga menempatkan Indonesia memiliki peringkat terendah ketiga dengan negara yang memiliki tingkat kemampuan membaca pemahaman rendah (OECD, 2013: 76).

Rendahnya kemampuan efektif membaca para siswa di sekolah, dalam pandangan peneliti merupakan cermin utama kegagalan pembelajaran membaca yang dilakukan di sekolah. Kegagalan ini dapat dimaklumi sebab berbagai pokok bahasan membaca yang disajikan di sekolah tidak pernah disertai dengan model membaca yang dapat digunakan untuk mendekati wacana tersebut. Tidak dikemasnya sistem pembelajaran membaca dengan tepat ini menyebabkan ratarata siswa hanya mampu membaca secara monoton, menerapkan gaya membaca yang sama untuk setiap bahan bacaan, bahkan lebih buruk lagi siswa tidak pernah tahu 
bagaimana cara praktis dalam memahami bacaan. Oleh sebab itu, peneliti bermaksud mengujicoba model pembelajaran yang dinilai tepat digunakan untuk meningkatkan kemampuan membaca pemahaman siswa melalui penelitian ini.

\section{METODE}

Metode penelitian yang digunakan dalam penelitian ini menggunakan Model kuasi eksperimen (Quasi Experimental Design) yang bertujuan untuk mengetahui efektivitas model problem based learning terhadap kemampuan membaca pemahaman siswa kelas V sekolah dasar.

Desain yang digunakan dalam penelitian ini adalah Nonequivalent Kontrol Group Design. Desain ini terdapat tiga kelompok (3 SD kelompok eksperimen dan 3 SD kelompok kontrol) yang dipilih secara acak kemudian diberi pretes untuk mengetahui keadaan awal adakah perbedaan antara kelompok eksperimen dan kelompok kontrol. Adapun kerangka desain penelitiannya (Sugiyono, 2010:79), sebagai berikut:

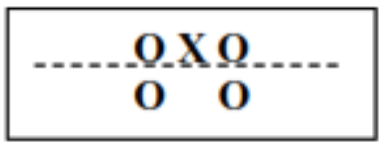

Keterangan :

O : Pretes/ postes berupa tes kemampuan membaca pemahaman $X$ : Perlakuan/ treatment dengan menggunakan Model problem based learning

Penelitian ini bertujuan untuk mengetahui efektifitas model pembelajaran Problem Based Learning terhadap kemampuan membaca pemahaman siswa kelas $\mathrm{V}$ Sekolah Dasar. Sekolah yang akan dijadikan lokasi penelitian adalah Sekolah Dasar yang berada di lingkungan UPT Kecamatan Depok
Kabupaten Cirebon diantaranya adalah SDN 1 Depok, SDN I Karangwangi, SDN I Keduanan, SDN I Waruroyom, SDN I Kasugengan Kidul, SDN 1 Kasugengan Lor. Setiap Sekolah

Dasar yang digunakan sebagai lokasi penelitian mempunyai karakteristik yang berbeda sehingga peneliti tertarik melakukan penelitian. Waktu yang akan dilaksanakan dalam penelitian ini adalah selama periode 1 tahun.

Berkaitan dengan Instrumen tes yang digunakan dalam penelitian,maka disusun instrumen penelitian untuk mengukur tingkat kemampuan membaca pemahaman siswa. Instrumen yang digunakan oleh peneliti adalah (1) lembar kerja proses (LKP) (2) tes kemampuan membaca pemahaman dengan menggunakan skoring rubrik sebagai sarana penilaian (3) catatan lapangan sebagai alat mengumpulkan data hasil observasi, (4) Pedoman wawancara untuk mengetahui respon siswa terhadap efektivitas penggunaan model pembelajaran Problem Based Learning, dan (5) dokumentasi untuk mengumpulkan mengumpulkan data selama proses penelitian.

Berdasarkan data yang diperoleh dalam penelitian ini yakni data kualitatif dan kuantitatif maka teknik yang akan digunakan untuk menganalisis data kualitatif adalah analisis secara deskriptif. Analisis deskriptif ini digunakan untuk mengetahui dan memperoleh gambaran mengenai efektivitas model 
pembelajaran Problem Based Learning dari segi proses pembelajaran

Selanjutnya teknik analisis data kuantitatif digunakan untuk mengetahui dan menjawab hipotesis penelitian yang berkaitan dengan perbedaan kemampuan antara pembelajaran dengan menggunakan model pembelajaran Problem Based Learning dengan pembelajaran konvensional. Tahapan analisis data kuantitatif akan menggunakan metode statistik yaitu uji beda (t) dengan bantuan SPSS versi 17 , selanjutnya untuk analisis perbedaan kemampuan awal membaca pemahaman dengan menggunakan N-Gain dengan bantuan SPSS.

Tahapan analisis data kuantitatif dengan menggunakan statistik dilakukan dengan beberapa tahapan. Tahapan-tahapan tersebut adalah (1) analisis data deskriptif, (2) analisis uji normalitas dan homogenitas, (3) analisis uji beda dengan menggunakan uji t atau uji lain yang sesuai, dan (4) analisis uji beda dengan menggunakan N-Gain.

\section{PEMBAHASAN}

Data Hasil Pretes Kelas telahdihasilkan data berupa skor Eksperimen. pretes kemampuan Membaca Berdasarkan hasil penskoran Pemahaman siswa. Data tersebut terhadap model pembelajaran

Problem Based Learning yang diterapkan pada saat pretes

Tabel 1. Hasil Pengolahan Data Pretes Kemampuan Membaca Pemahaman Kelas Eksperimen

\begin{tabular}{cc}
\hline & $\begin{array}{c}\text { Pretest Membaca } \\
\text { Pemahaman }\end{array}$ \\
\hline Valid & 81 \\
Missing & 0 \\
Mean & 6.3333 \\
Median & 6,0000 \\
Std. Deviation & 1,08397 \\
Variance & 1,175 \\
Range & 5,00 \\
Minimum & 4,00 \\
Maximum & 9,00 \\
\hline
\end{tabular}

Berdasarkan tabel 1, diperoleh kemampuan membaca pemahaman distribusi skor sebagai hasil siswa pada saat pretes adalah penelitian terhadap sejumlah 81 sebesar 6,33. Standar deviasinya siswa, diperoleh skor minimal 4 dan maksimal 9. Rentang yang merupakan skor maksimum dikurangi skor minimum adalah 5 , artinya jarak antara skor terkecil ke skor terbesar adalah 5 satuan skor. Skor rata-rata adalah sebesar 1,08 , artinya sebaran skor yang diperoleh adalah $1,08 \mathrm{di}$ sekitar skor rata- ratanya. Distribusi data penelitian tersebut dapat disajikan seperti pada gambar 1 . 


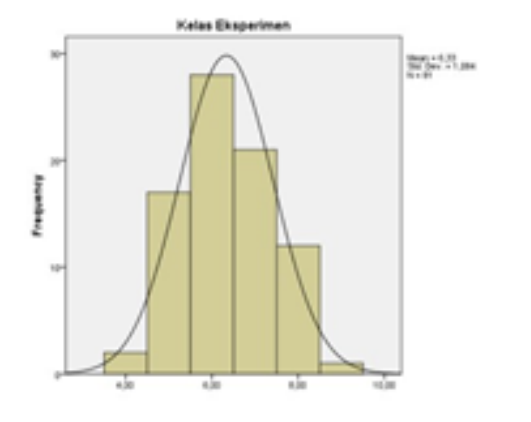

\section{Gambar 1 Histogram Data Pretes Kemampuan Membaca Pemahaman Kelas Eksperimen}

\begin{abstract}
Berdasarkan gambar 1, dapat dikemukakan bahwa skor pretes kemampuan Membaca Pemahaman berdistribusi dari 4 sampai dengan 9 . Distribusi ini dapat dikatakan cukup normal sejalan dengan garis normalitas yang terdapat pada gambar tersebut. Namun ditinjau dari rata-rata yang diperoleh, kemampuan Membaca Pemahaman siswa masih dikategorikan rendah.
\end{abstract}

\section{Data Hasil Posttes Kelas Eksperimen}

Berdasarkan hasil penskoran terhadap model pembelajaran Problem Based Learning yang diterapkan pada saat postes telah dihasilkan data berupa skor postes kemampuan membaca pemahaman siswa. Selanjutnya perolehan data tersebut diolah melalui tahap uji statistik deskriptif dengan menggunakan SPSS. Setelah dilakukan analisis data terhadap besaran- besaran statistika deskriptif, maka akan diperoleh angka-angka statistik sebagaimana yang tercantum dalam tabel 2 .

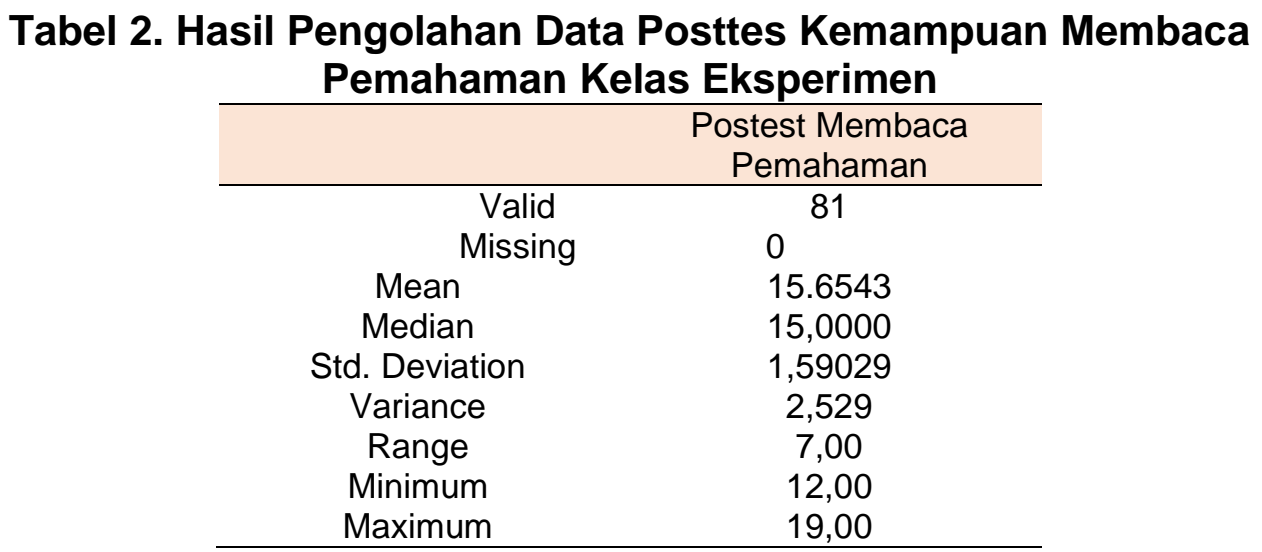

Berdasarkan 2, diperoleh distribusi skor sebagai hasil penelitian terhadap sejumlah 81 siswa, diperoleh skor minimal 12 dan maksimal 19. Rentang yang merupakan skor maksimum dikurangi skor minimum adalah 7 , artinya jarak antara skor terkecil ke skor terbesar adalah 7 satuan skor. Skor rata-rata kemampuan Membaca Pemahaman siswa pada saat postes adalah sebesar 15,65. Standar deviasinya adalah sebesar 1,59 , artinya sebaran skor yang diperoleh adalah 1,59 di 
sekitar skor rata- ratanya. Distribusi disajikan seperti pada gambar 2 . data penelitian tersebut dapat



\section{Gambar 2 Histogram Data Postes Kemampuan Membaca Pemahaman Kelas Eksperimen}

Berdasarkan gambar 2, dapat dikemukakan bahwa skor postes kemampuan Membaca Pemahaman siswa berdistribusi dari 12 sampai dengan 19. Distribusi ini dapat dikatakan cukup normal sejalan dengan garis normalitas yang terdapat pada gambar tersebut. Ditinjau dari rata-rata yang diperoleh saat postes, kemampuan Membaca Pemahaman siswa pada kelas eksperimen sudah mengalami peningkatan dibanding rata-rata skornya pada saat pretes. Skor hasil postesnya dapat dikategorikan cukup tinggi.
Data Hasil Pretes Kelas Kontrol.

Berdasarkan hasil penskoran terhadap model pembelajaran Problem Based Learning yang diterapkan pada saat pretes telah dihasilkan data berupa skor pretes kemampuan Membaca Pemahaman siswa. Selanjutnya perolehan data tersebut diolah melalui tahap uji statistik deskriptif dengan menggunakan SPSS. Setelah dilakukan analisis data terhadap besaran- besaran statistika deskriptif, maka akan diperoleh angka-angka statistik sebagaimana yang tercantum dalam tabel 3.

Tabel 3. Hasil Pengolahan Data Pretes Kemampuan Membaca Pemahaman

\begin{tabular}{cc}
\hline & $\begin{array}{c}\text { Pretest Membaca } \\
\text { Pemahaman }\end{array}$ \\
\hline Valid & 81 \\
Missing & 0 \\
Mean & 6,2840 \\
Median & 6,0000 \\
Std. Deviation & 1,26723 \\
Variance & 1,606 \\
Range & 6,00 \\
Minimum & 3,00 \\
Maximum & 9,00 \\
\hline
\end{tabular}

terhadap sejumlah 81 siswa, diperoleh

Berdasarkan tabel 3, diperoleh distribusi skor sebagai hasil penelitian skor minimal 3 dan maksimal 9 .

Rentang yang merupakan skor 
maksimum dikurangi skor minimum adalah 6 , artinya jarak antara skor terkecil ke skor terbesar adalah 6 satuan skor. Skor rata-rata kemampuan Membaca Pemahaman siswa pada saat pretes adalah sebesar 6,60. Standar deviasinya adalah sebesar 1,27 , artinya sebaran skor yang diperoleh adalah 1,27 di sekitar skor rata- ratanya.

Distribusi data penelitian tersebut dapat disajikan seperti pada gambar berikut.

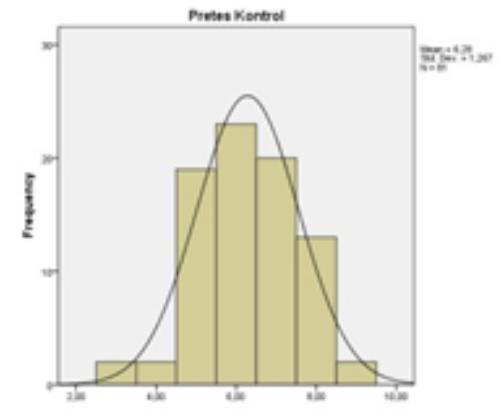

\section{Gambar 3. Histogram Data Pretes Kemampuan Membaca Pemahaman Kelas Kontrol}

dikemukakan bahwa skor pretes Problem Based Learning yang kemampuan Membaca Pemahaman diterapkan pada saat postes telah siswa berdistribusi dari 3 sampai dihasilkan data berupa skor postes dengan 9. Distribusi ini dapat dikatakan cukup normal sejalan dengan garis normalitas yang terdapat pada gambar tersebut. Ditinjau dari rata-rata yang diperoleh saat pretes, kemampuan siswa kelas kontrol dalam kemampuan Membaca Pemahaman masih dikategorikan rendah.

\section{Data Hasil Postes Kelas Kontrol. dalam tabel 4.}

Tabel 4. Hasil Pengolahan Data Postes Kemampuan Membaca Pemahaman Kelas Kontrol

\begin{tabular}{|l|l|r|}
\hline \multicolumn{2}{|l|}{} & \multicolumn{1}{|c|}{$\begin{array}{c}\text { Postes } \\
\text { Membaca } \\
\text { Pemahaman }\end{array}$} \\
\hline \multirow{2}{*}{} & Valid & 81 \\
\cline { 2 - 3 } & Missing & 0 \\
\hline Mean & 10,3210 \\
\hline Median & 10,0000 \\
\hline Std. Deviation & 1,75945 \\
\hline Variance & 3,096 \\
\hline Range & 7,00 \\
\hline Minimum & 7,00 \\
\hline Maximum & 14,00 \\
\hline
\end{tabular}


Berdasarkan tabel 4, diperoleh distribusi skor sebagai hasil penelitian terhadap sejumlah 81 siswa, diperoleh skor minimal 7 dan maksimal 14 . Rentang yang merupakan skor maksimum dikurangi skor minimum adalah 7, artinya jarak antara skor terkecil ke skor terbesar adalah 7 satuan skor. Skor rata-rata kemampuan Membaca Pemahaman siswa pada saat postes adalah sebesar 10,32. Standar deviasinya adalah sebesar 1,76 , artinya sebaran skor yang diperoleh adalah 1,76 di sekitar skor rata- ratanya.

Distribusi data penelitian tersebut dapat disajikan seperti pada gambar berikut.

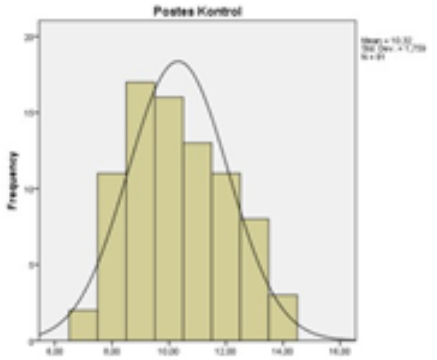

\section{Gambar 4. Histogram Data Postes Kemampuan Membaca Pemahaman Kelas Kontrol}

sebaran data hasil penelitian, maka

Berdasarkan gambar 4, dapat dikemukakan bahwa skor postes kemampuan Membaca Pemahaman siswa berdistribusi dari 7 sampai dengan 14. Distribusi ini dapat dikatakan cukup normal sejalan dengan garis normalitas yang terdapat pada gambar tersebut. Ditinjau dari rata-rata yang diperoleh saat postes kemampuan Membaca Pemahaman siswa pada kelas kontrol sudah mengalami peningkatan dibanding rata-rata skornya pada saat pretes. Namun demikian hasil postesnya dapat dikategorikan cukup.

Sehubungan dengan analisis data yang berdistribusi perlu diadakan sebuah pembuktian guna memberikan kepastian normal atau tidak sebuah data. Teknik yang dapat digunakan adalah Uji Chi Kuadrat. Sedangkan teknis pengujiannya dilakukan dengan menggunakan SPSS 18 yaitu data hasil penelitian diuji normalitasnya dengan menggunakan Uji Chi Kuadrat dan hasilnya dapat dinyatakan sebagai berikut.

Berdasarkan hasil pengolahan data uji normalitas dengan menggunakan Uji Chi Kuadrat terhadap data kemampuan Membaca Pemahaman siswa diperoleh besarandata yang telah dilakukan terhadap besaran statistika sesuai table 5 .

Tabel 5 Hasil Uji Normalitas Kemampuan Membaca Pemahaman

\begin{tabular}{|l|r|r|r|r|}
\hline & $\begin{array}{c}\text { Pretes } \\
\text { Eksperimen }\end{array}$ & $\begin{array}{c}\text { Pretes } \\
\text { Kontrol }\end{array}$ & $\begin{array}{c}\text { Postes } \\
\text { Eksperi } \\
\text { men }\end{array}$ & $\begin{array}{c}\text { Postes } \\
\text { Kontrol }\end{array}$ \\
\hline $\begin{array}{l}\text { Chi- } \\
\text { square }\end{array}$ & $42,185^{\mathrm{a}}$ & $46,123^{\mathrm{a}}$ & $40,580^{\mathrm{b}}$ & $21,025^{\mathrm{b}}$ \\
$\mathrm{df}$ & 5 & 7 & 6 & 7 \\
$\begin{array}{l}\text { Asymp. } \\
\text { Sig. }\end{array}$ &, 000 &, 000 &, 000 &, 000 \\
\hline
\end{tabular}


Berdasarkan normalitas di atas dapat diketahui bahwa nilai Chi Kuadrat untuk keempat data yang telah dilakukan pengujian pada sebaran data hasil penelitian adalah sebesar 42,18, $40,58,46,12$, dan 21,02. Nilai df atau derajat kebebasan diperoleh dengan nilai sebesar 5, 7, 6 dan 7 . Sedangkan nilai Asymp. Sig. pada keempat data di atas masing-masing diperoleh sebesar $0,00,0,00,0,00$, dan 0,00. Ternyata nilai Asymp. Sig. lebih kecil daripada nilai taraf nyata (a) yang telah ditetapkan yakni sebesar 0,05. Dengan demikian, keempat kelompok data dikategorikan tidak berdistribusi normal.

Melihat kasus di atas bahwa Uji Chi Kuadrat menghasilkan data tidak
5, berdistribusi normal. Sehingga perlu dilakukan uji statistika non parametris dengan menggunakan uji ManWhiteney U. Pengujian ini bertujuan untuk mengetahui tingkat Homogenitas (kesamaan kemampuan) pada tahap pretes dan postes antara kelas eksperimen dan kelas kontrol dalam kemampuan membaca pemahaman siswa. Lebih lanjut pengujian ini beguna pula untuk membuktikan hipotesis yang telah diajukan dalam penelitian ini.

Hasil pengujian dua rerata pretes antara kelas eksperimen dan kelas kontrol dengan menggunakan uji ManWhiteney $U$ diperoleh hasil sesuai tabel 6 .

\section{Tabel 6. Hasil Uji Man- Whiteney U. Data Pretes Kemampuan Membaca}

Pemahaman

\begin{tabular}{|l|r|}
\hline \multicolumn{1}{|c|}{ Hasil Uji Man- } \\
Whiteney U Data \\
Pretes Kemampuan \\
$\quad$ Membaca \\
Pemahaman antara \\
Kelas Eksperimen \\
dan Kelas Kontrol & \multicolumn{1}{c|}{ Nilai } \\
\hline $\begin{array}{l}\text { Mann-Whitney U } \\
\text { Wilcoxon W }\end{array}$ & 3233,500 \\
Z & 6554,500 \\
Asymp. Sig. (2- &,- 163 \\
tailed) &, 871 \\
\hline
\end{tabular}

\begin{tabular}{|l|l|c|c|c|}
\hline & \multicolumn{1}{|c|}{ Kelas } & $\mathrm{N}$ & $\begin{array}{c}\text { Mea } \\
\mathrm{n} \\
\text { Rank }\end{array}$ & $\begin{array}{c}\text { Sum of } \\
\text { Ranks }\end{array}$ \\
\hline $\begin{array}{l}\text { Nil } \\
\text { ai }\end{array}$ & $\begin{array}{l}\text { Pretes } \\
\text { Eksperimen } \\
\end{array}$ & 81 & 82,08 & 6648,50 \\
& Pretes Kontrol \\
& Total & 81 & 80,92 & 6554,50 \\
\hline
\end{tabular}

Berdasarkan tabel 6 telah diketahui bahwa nilai Mann-Whitney U yang dihasilkan sebesar 3233,50 . Nilai Sig. (2-tailed) diperoleh sebesar 0,871 . Ternyata perolehan Nilai Sig. (2-tailed) lebih besar dari taraf nyata yang diajukan sebesar 0,05 $(0,871>0,05)$. Dengan demikian, dapat dibuktikan bahwa tidak terdapat perbedaan yang signifikan antara

pretes kemampuan membaca pemahaman siswa di kelas eksperimen dan kelas kontrol. Pembuktian lainnya diperkuat oleh nilai Mean Rank antara pretes kelas eksperimen dan pretes kelas kontrol yaitu pada kelas eksperimen sebesar 82,08 sedangkan pada saat postes mencapai 80,92 dengan besar perbedaan sebesar 1,16. 
Hasil pengujian dua rerata Man-Whiteney $U$ diperoleh hasil postes antara kelas eksperimen dan sesuai table 7.

kelas kontrol dengan menggunakan uji

Tabel 7 uji Man-Whiteney U Data Prostes Kemampuan Membaca

Pemahaman antara Kelas Eksperimen dan Kelas Kontrol
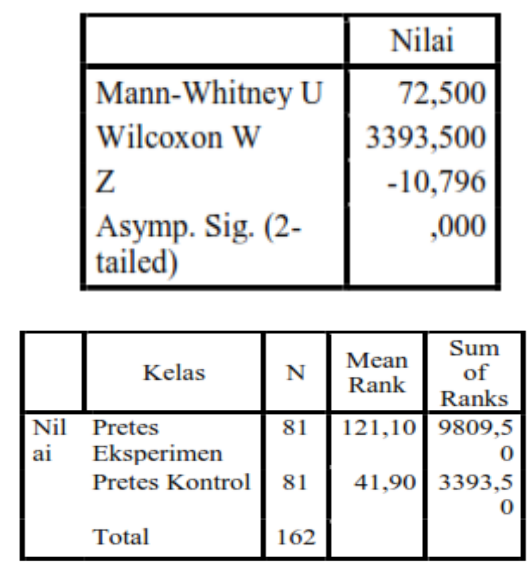

Berdasarkan tabel 7 telah diketahui bahwa nilai Mann-Whitney $U$ yang dihasilkan sebesar 72,50. Nilai Sig. (2-tailed) diperoleh sebesar 0,00. Ternyata perolehan Nilai Sig. (2-tailed) lebih kecil dari taraf nyata yang diajukan sebesar $0,05 \quad(0,00<0,05)$. Dengan demikian, dapat dibuktikan bahwa terdapat perbedaan yang signifikan antara postes kemampuan membaca pemahaman siswa di kelas eksperimen dan kelas kontrol. Pembuktian lainnya diperkuat oleh nilai Mean Rank antara postes kelas eksperimen dan postes kelas kontrol yaitu pada kelas eksperimen sebesar 121,10 sedangkan pada saat postes mencapai 41,90 dengan besar perbedaan sebesar 79,20. Melihat ketercapaian uji Mann-Whitney $U$ ini berarti penerapan model pembelajaran Problem Base Learning pada kelas eksperimen dan model lain di kelas kontrol telah memberikan pengaruh positif bagi peningkatan kemampuan membaca pemahaman siswa.

Berdasarkan data-data yang telah dikemukakan tersebut dapat diketahui bahwa kemampuan membaca pemahaman siswa melalui model pembelajaran PBL menunjukkan hasil yang lebih baik. Efektifivitas ditunjukkan pada peningkatan nilai prates dan posttes di kelas eksperimen lebih baik dibandingkan dengan di kelas kontrol.

Keberhasilan peningkatan kemampuan membaca pemahaman siswa ini tentu sesuai dengan kelebihan model PBL yang dapat menjadi salah satu sarana proses pembelajaran yang mengutamakan proses berpikir yang mendalam untuk mencapai suatu tujuan pembelajaran yang ditetapkan.

\section{SIMPULAN}

Berdasarkan hasil penelitian yang telah dilakukan, ada dua simpulan yang peneliti peroleh. Pertama, kemampuan awal membaca pemahaman antara kelas eksperimen dan kelas kontrol adalah sama. Hal ini menunjukkan bahwa kedua kelas memiliki kemampuan awal yang relatif 
sama. Kedua, kemampuan membaca pemahaman kelas eksperimen dan kelas kontrol dalam posttes menunjukkan perbedaan. Kelas eksperimen yang menerapkan model pembelajaran $\mathrm{PBL}$ menunjukkan kemampuan membaca pemahaman yang lebih baik daripada kelas kontrol. Dengan demikian, kelas eksperimen yang menerapkan model pembelajaran PBL lebih efektif dalam meningkatkan kemampuan membaca pemahaman siswa dibandingkan dengan kelas kontrol

\section{DAFTAR PUSTAKA}

Abidin, Y. (2013). Pengembangan Model Penilaian Otentik dalam Pembelajaran Membaca Pemahaman di Sekolah Dasar. Disertasi. (Tidak diterbitkan), Bandung: UPI.

Abidin, Y. (2014). Desain Sistem Pembelajaran dalam Konteks Kurikulum 2013. Bandung: Refika Aditama.

Arends Richard I. (2008). Learning to Teach: Belajar untuk Mengajar. Yogyakarta: PustakaPelajar.

Concannon-Gibney, T. dan McCarthy, M.J. (2012). The Explicit Teaching of Reading Comprehension in Science Class: a Pilot Professional Development Program. Improving Schools. 15 (1). 7388.

Croninger, R.G. danValli, L. .(2009). Where Is the Action?' Challenges to Studying the Teaching of Reading in Elementary Classrooms. Educational Researcher. 38 (2). 100-108.

Febriyanto (2016). Penerapan Model Cooperative Integrated Reading And Composition Dalam Pembelajaran Keterampilan Membaca Pemahaman. Jurnal Cakrawala Pendas. 2 (2). 42-57.

Gunantara G, Suarjana M, Riastini, N. (2014). Penerapan Model Pembelajaran Problem Based Learning Untuk Meningkatkan
Kemampuan Pemecahan Masalah Matematika Siswa Kelas V. Jurnal Mimbar PGSD Vol: 2 No: 1 . Universitas Pendidikan Ganesha Jurusan PGSD.

Hosnan. (2014). Pendekatan Saintifik Dan Kontekstual Dalam Pembelajaran Abad 21 Kunci Suskes Implementasi Kurikulum 2013. Bogor: Ghalia Indonesia.

Jhonson, P. Andrew. (2008). Teaching And Writing: Guidebook For Tutoring And Remediating Students. New York: United Kingdom.

OECD. (2013). Literacy Skills for Tomorrow: Futher Results From PISA 2000. Canada: OECD.

O'Reilly, T. dan McNamara, D.S. (2007). The Impact of Science Knowledge, Reading Skill, and Reading Strategy Knowledge on More Traditional "HighStakes" Measures of High School Students' Science Achievement. American Educational Research Journal. 44 (1). 161-196.

Rayner, K. et al. (2001). How Psychological Science Informs the Teaching of Reading. Psychological Science in The Public Interest. 2 (2).31 - 74.

Sugiyono. (2013). Model Penelitian Kombinasi (Mix Methods). Bandung: Alfabeta. 
Swanson, E., et al. (2011). Applying a Cohesive Set of Comprehension Strategies to Content-Area Instruction. Intervention in School and Clinic. 46 (5). 266272 